\title{
An Ideological Analysis of the Former President Donald Trump's Tweets During COVID-19
}

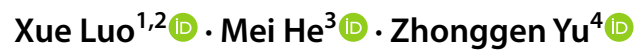

Received: 17 July 2021 / Accepted: 20 November 2021 / Published online: 11 December 2021

(c) The Author(s), under exclusive licence to Springer Nature Switzerland AG 2021

\begin{abstract}
This study aimed to explore the former US President Donald Trump's representation of "us" and "others" in his tweets related to COVID-19 and how he portrayed the representation of "us" and "others". In this study, the sample related to COVID-19 which ranged from January to May 2020, consisted of the tweets posted by the former US President Donald Trump. To analyze the ideological discourse of the former President Donald Trump's tweets during COVID-19, the ideological framework proposed by Van Dijk (Approaches to Media Discourse. Blackwell Publishing, 1997) was adopted to reveal the underlying intentions and ideologies of $u s$-representation and others-representation. The results of this research indicate that Donald Trump portrayed a positive us-group and a negative others-group. Moreover, argumentation/authority, comparison, repetition, capitalization, and metaphors are the typical strategies that former President Trump used to portray both groups. It was also found that the positive opinions about the us-group and the negative ones about the others-group were not always consistent. For example, there were also changes when the same descriptions were given to both groups, which may well be coherent concerning the basic interests of the groups (Van Dijk, in: Approaches to Media Discourse. Blackwell Publishing, 1997). The findings of this study may contribute to an analysis of the president's discourse on Twitter, which is a relatively recent channel for political information (Kerbleski, in: Trump, Twitter, and the trees: a critical discourse analysis of Donald Trump's tweets surrounding the november 2018 California Wildfires. Doctoral dissertation, Northern Arizona University, 2019).
\end{abstract}

Keywords Ideological discourse analysis · Donald Trump · Tweets · COVID-19

Zhonggen $\mathrm{Yu}$

401373742@qq.com

Extended author information available on the last page of the article 


\section{Introduction}

Twitter has become a powerful interface of political communication and interaction and is overtaking the traditional means of mass communication (Tasente, 2020). The use of Twitter by state leaders had a significant impact on the public during the COVID-19 pandemic, and many (64.8\%) UN member states leaders reacted to the pandemic COVID-19 on Twitter (Haman, 2020). Shafer (2017) reports that characterized by free expression and easy interaction, Twitter has become a widely used platform in political campaigns, resulting in a greater presence of political parties, candidates, and journalists on Twitter to disseminate their personal political attitudes and ideas.

Among the users, the former US President Donald Trump is one of the most active who have exerted an influence on society, economy, and international relations, which has been labeled the "Trump Effect" and affected millions of people worldwide (Bustan \& Alakrash, 2020). A study also showed that Trump's Tweets had a directional effect on European stocks (Klaus \& Koser, 2021). Thus, there is great interest in studying his tweets to explore his use of linguistic features and the ideology behind them. For example, Piksar (2018) conducted a study on Donald Trump's political discourse on Twitter from a Critical Discourse Analysis (CDA) perspective, and demonstrated that by using nomination, argumentation, and intensification strategies, Donald Trump presented himself positively and painted himself as a victim by criticizing news organizations for delivering "fake news", as he described them, to arouse sympathy from his audience. In addition, Bustan and Alakrash (2020) found that Donald Trump adopted various linguistic devices, such as metaphors, repetition, hyperbole, and modal verbs to present a picture of a positive "Us" and a negative "Others". Furthermore, other researchers also found positive self-representation and negative others-representation (e.g., Kerbleski, 2019; Ott, 2017; Rohmah, 2018). Specifically, sexist ideology was implicitly represented in some of his tweets (Darweesh \& Abdullah, 2016) and also anti-Muslim-Islam ideology was revealed (Khan et al., 2019).

Recently, COVID-19, or Corona Virus Disease, was announced by World Health Organization as a worldwide pandemic in March 2020, which was an issue repeatedly addressed in Donald Trump's Twitter. In terms of in-degree centrality and content presented in tweets, Donald Trump played a significant role in the social networks, and more importantly, he exerted a crucial influence on the worldwide news concerning COVID-19 (Yum, 2020). According to a study conducted by Budhwani and Sun (2020), which demonstrated that after Donald Trump referred to COVID-19 as a "Chinese virus" and a "China virus", there was a significant increase of similar phrases in terms of frequency and prevalence. Previous studies (e.g., Mena García, 2018; Tasente, 2020) revealed that ideologies were embedded in Donald Trump's tweets. However, to date, there have not been any studies on the specific ideology presented in Donald Trump's tweets related to COVID-19. In particular, due to the large number of confirmed cases of COVID-19, it is important to explore how the US statesman portrays this situation. Therefore, the present research tries to explore the representation of the 
"Us" and "Others" groups on Twitter by Donald Trump and how both groups are portrayed. From the perspective of CDA, more insights are integrated through the studies of pragmatics as a means of exploring the hidden meanings behind the texts.

\section{Literature Review}

\section{A critical Discourse Analysis Framework}

A critical discourse analysis (CDA) examines how discourses are able to construct, maintain, and legitimize social inequalities (Wodak, 2001). Ideologies and power can be demystified by investigating written, spoken, or visual data in a systematic and reproducible way (Wodak \& Meyer, 2009). CDA assumes that our use of language is purposeful, whether we are conscious of it or not (Mullet, 2018). Teguia (2019) proposed that in a social field, politics is the most appropriate area for CDA to work in. Politicians and presidential candidates fight over ideologies in parliaments and political debates. Except for studies of identity (Kang \& Dykema, 2017; Rahimpour et al., 2018), and cultural representations in books (Davari \& Moini, 2016; Leung, 2016; Samadikhah \& Shahrokhi, 2015; Sarani \& Kord, 2018), CDA has also been applied to studies on social media discourse (Ott, 2017; Rohmah, 2018; Teguia, 2019; Zahra, 2019).

Applying this approach to a political discourse analysis, Farrelly (2019) claimed that an analysis of how policymakers and legislators portrayed social actors in texts could provide valuable insight into their conceptualization of the objects of governance. Martin (2013) stated that politicians made use of all their linguistic techniques to express their feelings and ideas to deliver their ideologies implicitly which exerted a crucial influence on their audience. Hence, the purpose of CDA in political discourse is to investigate what is meant by their use of linguistic devices to examine the latent ideologies. Among popular CDA frameworks, the one proposed by Van Dijk (1997) was selected as the theoretical basis of this study.

Van Dijk (1997) defined ideologies as the basic principles of "socially shared representations of groups about themselves and their relations to other groups, including such categories as membership criteria, activities, goals, values, and crucial group resources" (p 43). Moreover, the continuing social conflict is represented in a polarized way according to the categorization of $U s$ vs. Them or Us vs. Others. More specifically, there is a positive self-presentation and negative other-presentation. To find out what lies behind these ideologies, Van Dijk (1997) proposed a basis for an ideological analysis. The first step was to examine the discourse contexts. Secondly, researchers analyzed both positive and negative groups such as us and others involved in their power relations and conflicts. Thirdly, researchers examined the presuppositions and implications of both groups. The last step was to explore all the formal structures that stress or mitigate the polarized group opinions. 


\section{Research on Trump's Tweets}

As one of the most active Twitter users, Donald Trump has attracted some scholars' attention due to his special discourse on tweets. Previous studies were conducted to investigate his tweets both in general (Piksar, 2018; Tasente, 2020) and in particular (Bustan \& Alakrash, 2020; Yaqub et al., 2017), as well as the specific ideologies embedded in his tweets (Darweesh \& Abdullah, 2016; Lockhart, 2019; Zahra, 2019).

Many researchers focused on exploring frequent expressions, discourse strategies, and the representation of Trump himself and others in Trump's tweets. To determine the communication orientation, Tasente (2020) identified the most frequent expressions in Donald Trump's tweets, which established a basis for further studies. Piksar (2018) further explored the discourse strategies and the representation of Trump himself and others in Trump's tweets. It was found that Trump intended to portray himself positively by criticizing others or by presenting others in a negative way through nomination, argumentation, and intensification. Furthermore, Mena García (2018) identified Trump's use of metaphors to express his ideologies and he presented immigrants and bureaucrats negatively, which revealed the main features of Trump's tweets including simplicity, repetition, parataxis, and hearsay evidence. Similarly, Rohmah (2018) argued that Trump intentionally made a negative representation of other groups to highlight himself positively by means of repetition, irony, and pronouns.

There are many studies on Trump's tweets with regard to particular events. Yaqub et al. (2017) conducted a sentiment and impact analysis of tweets delivered by Trump and Hillary Clinton during the 2016 US presidential elections and discovered that Trump revealed a more optimistic campaign message. Schertzer and Woods (2021) also analyzed 5,515 tweets sent by Trump during the 2016 presidential campaign and found that most of his tweets revealed ethno-nationalist and populist themes. Furthermore, Teguia (2019) explored forty tweets posted by Trump related to the issue of the border wall and showed that people were incentivized by Trumpism due to his hostility to and persecution of Mexicans in his tweets in order to frame the ideology that building the border wall was a 'must.' Platformed racism was embedded in Trump's tweets. In addition, Trump's tweets addressing the California wildfires (Kerbleski, 2019) were also examined. Characterized by over wording, undefined agency, and capitalization, his tweets indicated the ideology of national identity and authenticity. Exploring his tweets related to Middle Eastern countries, Bustan and Alakrash (2020) showed that Trump preferred metaphors, repetition, hyperbole, and modality in his tweets and repeatedly used "us" to convey the togetherness of Americans.

Furthermore, some specific ideologies presented in Trump's tweets have been unearthed. Darweesh and Abdullah (2016) revealed that Trump possessed a masculine point of view and implicitly expressed the superiority of males over females. Moreover, his tweets were founded on racism (Zahra, 2019) which implied Islamophobic, anti-immigrant, and anti-refugee positions. In addition, an anti-Muslim attitude was embedded in his tweets (Khan et al, 2019). 
From the above studies, it can be seen how some discourse strategies and several ideological stances were implied in Trump's tweets (Mena García, 2018; Tasente, 2020; Teguia, 2019; Zahra, 2019). There were always specific intentions behind Trump's words, which exerted a crucial influence on readers. Ross and Caldwell (2020) claimed that Trump used negativity as a rhetorical political strategy. However, he also utilized an appraisal system to attack and insult opponents. His personal Twitter account frequently posted some tweets related to COVID-19 which became a worldwide pandemic in the year 2020. However, studies demonstrating what ideologies were embedded in tweets relating to COVID-19 are scarce. Surprisingly, after his tweets referred to COVID-19 as the "Chinese virus" or "China virus", there was a tenfold increase in the use of these phrases on Twitter (Budhwani $\&$ Sun, 2020). Proceeding on this basis, the present study aims to integrate CDA into his tweets related to COVID-19 and to answer the following two research questions:

RQ1. What representation of "us" and "others" does Donald Trump use in his tweets related to COVID-19?

RQ2. How does Donald Trump portray the representation of "us" and "others"?

\section{Methodology}

\section{Data Collection}

The data, related to COVID-19, were collected from the tweets posted by US Donald Trump. There is a Trump Twitter Archive (http://www.trumpTwitterarchive. com/) which collected all his tweets from his personal Twitter account @ realDonaldTrump. The study collected the data ranging from January to May in 2020. The reason for starting from January 2020 is that China reported the first confirmed case of COVID-19 at that time. Then, the researchers picked out all his posted tweets related to COVID-19 during this period. Finally, 128 tweets were compiled for the present corpus and labeled from T001 to T128 chronologically. Moreover, a logbook for each tweet was created including the numbers of words, likes, retweets, and comments to obtain a picture of the influence of his tweets.

\section{Data Analysis}

After all the data were collected, a textual analysis was conducted based on the ideological framework proposed by Van Dijk (1997). To answer the first research question, the context and background of the tweets were obtained from the literature. Then all the groups, countries, and individuals involved, which were called actors as well, were identified, and all the contents referring to them were retrieved respectively. By perusing all the references, all the involved actors were divided into usgroup and others-group. Within each group, recurrent themes were found and the relevant contents were grouped to examine the positive and negative expressions of Us and Others. 
To answer the second research question, the contents which carry meaning and implied ideologies were investigated carefully. The strategies adopted were identified to reveal the implicit intentions of $u s$-representation and other-representation, thus the illustrations were interpreted, and the findings were compared with those of previous related studies.

As the coding process involved subjective judgments to a certain degree, the second researcher would act as an inter-rater to code the data independently utilizing the pilot codes identified by the first researcher. At the same time, new themes were allowed to emerge. After coding, the disagreement and discrepancies were discussed until a final agreement was reached. Then, the codes were fine-tuned and the points of disagreement were re-coded.

\section{Results and Discussion}

\section{Representation of "Us" and "Others"}

After the tweets were collected and analyzed, descriptive statistics showed that the average number of words in each tweet was 38, the average number of likes was 41,900 , and the average number of retweets was 28,700 . In the comment section of each tweet, the average number of comments was 89,700 . From the average numbers, it can be seen that Donald Trump played a crucial role in the news of COVID19 (Yum, 2020). His tweets continuously attracted public interest. What he tweeted exerted a significant impact on the ideological issues related to COVID-19.

In line with Van Dijk (2006), actors may be described as members of groups or individuals. After a detailed analysis of all the 128 tweets (T001-T128), it was found that there was a total of 27 actors described as "us", while 16 actors were represented as "others". After grouping the related descriptions of each actor, this study found five themes related to the us-group: (1) America as a monitor; (2) America as a winner; (3) America as superior; (4) Trump himself as a hero; and (5) Trump himself as an authority. Furthermore, four themes were indicated in the others-group, which were (1) China blamed; (2) WHO blamed; (3) Democrats are incompetent; (4) Fake news media (Table 1).

It can be seen from Table 1 that Donald Trump endows the us-group with positive properties. The first category which showed this positive image was that Donald Trump shaped the "us" group as the monitor. "In very close communication with China" and "strongly on watch" extracted from tweet T002 probably implied the "us" group are keeping track of how China is dealing with coronavirus and the "us" group is watching the cases reported in the USA. The "us" group checked the epidemic information and monitored how others were monitoring events. In Tweet 003 (T003), the "us" group "continue to monitor the ongoing developments", which may reveal the same theme as the monitor.

America as a winner is the second category which can be concluded from the tweets. It indicated that he had a positive attitude towards the outbreak of COVID-19 and showed confidence in containing the pandemic. "The coronavirus is very much under control in the USA" and there were "only 5 people" (T004) with coronavirus 
Table 1 Themes of Trump's tweets

\begin{tabular}{l}
\hline Categories with examples \\
\hline 1. America as a monitor \\
Have a conversation with \\
To monitor the ongoing developments \\
Offer help \\
2. America as a winner \\
Very much under control \\
Only 5 people \\
Great job \\
3. America as superior \\
Best experts anywhere \\
Testing is sooo much better than any other country \\
Set a high standard for others to follow \\
4. Trump himself as a hero \\
Have done a very good job from the beginning \\
Made everyone look happy \\
5. Trump himself as an authority \\
I was right, he is incompetent \\
Like I say, they are fake news \\
1. China blamed \\
Chinese virus \\
Its sources \\
Incompetence of China \\
Did this mass Worldwide Killing \\
2. WHO blamed \\
Why did WHO ignore \\
Either inaccurate or misleading \\
3. Democrats are incompetent \\
Do nothing \\
Wasting time \\
Do harm \\
4. Fake news media \\
Disinformation \\
They are fake news \\
Far beyond what the facts would warrant \\
\end{tabular}

he tweeted on January $30^{\text {th }}$ at the very beginning of the outbreak, which probably meant there were only 5 confirmed cases in America, and they were all in a good condition. His tweets suggested that he believed the US was winning the battle against COVID-19, and that it had done a very good job until then. To show the success that had been achieved, he tweeted that America was "getting great marks for the handling of the pandemic" (T108), helping other countries and "saved many lives with our fast action" (T095), which basically implied that America is a winner because America is successful due to his hard work.

The third category drawn from the tweets described America as superior to other countries when it with regard to COVID-19, and his tweets indicated that "us" (America) had a higher rank and quality of experts and testing than other countries 
in the world. This is illustrated by "us" have "the best experts in the world" (T003), and "our testing is sooo (sic) much better than any other country" (T101). In addition, the White House Corona Virus Task Force "has done a fantastic job which will set a high standard for others to follow" (T107). "We", "our", and "Our White House Corona Virus Task Force" in the tweets refer to America. This infers that America is a country which surpasses any other country in the quality of its experts and testing. In other words, America is superior.

Through Trump's tweets, it was also signified that he portrayed himself as a hero, through his great achievements in dealing with the outbreak of a pandemic. For example, in T059 and T018, he praised himself for having done a very good job since the outbreak including his very early decision to close the borders from China, and in T105 he said, compared with Mexico, people in California are "so lucky" to have him as their president. It implied that he did a better job than the leaders in Mexico in dealing with coronavirus. Moreover, he also showed his noble qualities like his courage and care for others. He said that he was proud of taking some measures against the wishes of many people, which "made everybody look good" (T114) to save lives. This finding agrees with Kerbleski (2019), who argues that one of the ideological themes in Trump's tweets is his appeal to cultural heroism. In American culture, heroes, who should be respected and appreciated, are those full of bravery or emergency respondents in the face of tragedy and danger.

Finally, it was also found that Donald Trump argued that he had the authority to influence or command thoughts, opinions, or behaviors. For example, he stated that "I was right. He is incompetent" in T008. He believed his judgment is right but his arguments are subjective. Likewise, T016 signifies that Donald Trump reemphasized his judgment "like I say, they are Fake News!". Van Dijk (2006) argued that many speakers in an argument have recourse to mentioning authorities to support their case, who are usually organizations or people who are above the fray of party politics, or those generally recognized experts or moral leaders. In the present study, Trump regarded himself as the authority and he has the power to judge.

Furthermore, in the tweets, Donald Trump presented the others-group as well. China as one of the others-group and is blamed for the coronavirus. "Chinese virus" and "China virus" appeared 9 times in all the collected tweets. According to the World Health Organization (WHO) Best Practices for the Naming of New Human Infectious Diseases issued in May 2015, naming a disease should not include geographic locations such as cities, countries, regions, and continents. For example, names like Middle East Respiratory Syndrome, Spanish Flu, Rift Valley fever, Lyme disease, Crimean Congo hemorrhagic fever, and Japanese encephalitis should be excluded. Therefore, Donald Trump broke this rule by saying "Chinese Virus" instead of COVID-19 which is the appropriate name used by WHO. Van Dijk (2006) claims that propositions may be implied because they are presumed or presupposed to be known or true. However, such propositions may not be true at all. Donald Trump's inappropriate naming may embody racism. The use of "Chinese virus" and "China virus" presumes that America has nothing to do with the virus and that America is a victim of the outbreak of COVID-19. Dijk (2006) notes that others tend to be represented in negative terms, especially when associated with threats, so the "us" group needs to be represented as a 
victim. Likewise, in T118, Donald Trump blames China for its incompetence and being responsible for worldwide deaths, which may not be true at all. Interestingly, there were some positive descriptions about China at first, but later negative representations were used. The reason for this may be that America had few cases at the beginning while later it had the largest number of confirmed cases in the world. Thus, Donald Trump seems to blame China for COVID-19 and he implies that America is the victim.

The second category of negative representations of the others-group blames WHO for COVID-19. Questions using wh-words like "why" are tweeted by Trump to blame WHO for its inaccurate or misleading information, which may not be agreed by other people. For example, "Why did WHO make several claims about the Corona Virus that are either inaccurate or misleading...?" (T086) and "Why did the WHO wait as long as it did to take decisive action?" (T087). Trump used three wh-questions with "why" to emphasize WHO's bad actions from Trump's perspective.

It can also be shown that Democrats, as the opposition party to Republicans, are described as incompetent. In all the 128 tweets, Donald Trump tweeted "The Do Nothing..." to describe Democrats 5 times while Democrats in total were mentioned 12 times. He gives the nickname of "The Do Nothing Democrats" to Democrats to blame and criticize them as incompetent. T018 shows Democrats are blamed by him for wasting time on the Immigration Hoax and making the Republican Party look bad. As is known to all, Donald Trump belongs to the Republican Party which is the "us" group. So in his tweets, he described the Democratic Party as incompetent.

The last category showing the representation of the others-group is the Fake News media. In Trump's tweets, there are some news media which are described as fake news. He believed that these fake news media deliberately made the coronavirus look as bad as possible. For example, in T024 and T031, Donald Trump blamed MSDNC for covering "the Corona Virus situation horribly", which will "do harm to the incredible and successful efforts being made". He also criticizes some fake news media for inflaming the coronavirus situation "far beyond what the facts would warrant".

Whether or not in combination with the derogation of out-groups, group-talk is often characterized by another overall strategy, namely that of in-group favoritism or "positive self-presentation" (Chiluwa \& Ajiboye, 2015; Van Dijk, 1997, 2006; Van Holm, et al., 2020). This may signify that the speaker emphasizes the positive characteristics of his own group, such as his own party, or his own country. In the context of tweets related to COVID-19, Donald Trump portrayed an image of positive self-representation by stressing that he has done a great job and worked hard in containing the pandemic. Positive self-presentation is essentially ideological because it is based on the positive self-schema that defines the ideology of a group. While negative others-presentation also serves to emphasize the positive properties of the $u s$ group, as mentioned in the four squares of Van Dijk (1997). From the image Donald Trump portrayed in his tweets of the us-group and the others-group, the positive use of "us" and the negative use of "others" showed his appeal to nationalism and cultural heroism, which were also highlighted in previous studies (Kerbleski, 2019). 


\section{Strategies of Representation for "Us" and "Others"}

After investigating how Donald Trump described the representation of "us" and "others" in his tweets related to COVID-19, we found that argumentation, comparison, repetition, capitalization, and metaphors were the typical strategies used by Donald Trump to portray the positive us-group and the negative others-group.

In terms of argumentation, opinions usually need some support. Opinions are preceded or followed by a sequence of assertions that make them more plausible by various rules of inference, based on attitudes and values (Dijk, 2006). For example, Donald Trump employed " $96 \%$ approval rating" to argue that he did a great job in the handling of the pandemic. Moreover, he asserted that "our professionals are doing a great job" (T021) by listing the results reported by New York Post that "77\% of U.S. adults have confidence in their government's ability to handle the coronavirus (No. 1)" (T021).

Apart from argumentation, a comparison was frequently adopted by Donald Trump to stress positivity. Comparisons typically occur when speakers compare ingroups and out-groups (Van Dijk, 2006). Comparisons were mainly made by means of evaluation, actions taken to control the pandemic, and the results of a different pandemic handled by the former President Obama.

An evaluation was expressed by words like "great" (38 times), "good" (16 times), "correct", "right", "successful", "fantastic", and "perfectly" which shaped a positive image to describe the us-group. However, a great deal of vocabulary like "incompetent", "badly", "poor", "irresponsibly", "poorly", "sad", "bad", and "stupid" were used to evaluate the others-group. This is consistent with previous studies finding that emotionally charged and negative words were more commonly used in tweets written by Trump (Clarke \& Grieve, 2019; Chiluwa \& Ajiboye, 2015; Yaqub et al., 2017). Taiwo (2007) further claimed that 'emotive vocabulary' and 'rhetorical graphological devices' are used in social media to convey ideological views about people and situations. The choice of certain sets of vocabulary or patterns of framing ideas rather than other available options reveals something about their intentions, whether knowingly or unknowingly (Baker, 2006). This choice is always significant particularly because of its power to shape people's perceptions of social realities. In order to show visual presentation of such evaluative words, WordArt.com, an online word cloud creator, was used to generate word clouds of the vocabulary Donald Trump used to describe the us-group and the others-group respectively (Figure 1). In word clouds, more frequently used words are illustrated by larger fonts. It can be seen from the figure that Donald Trump used more positive words to describe the us-group but more negative words to describe the others-group, which is in line with studies conducted by other researchers (e.g., Chiluwa \& Ajiboye, 2015; Van Dijk, 1997, 2006; Van Holm, et al., 2020).

Apart from the extensive use of words for evaluation, Trump compared his actions against the outbreak of COVID-19 with those of the Democrats. He claimed that "The Do Nothing Democrats" were "busy wasting time on the Immigration Hoax while he was busy calling for early border and flight closings which were thought to be the right decision" (T018). He strongly emphasized that as a result of his appropriate and quick action he succeeded in putting 'us' (America) way ahead in the 

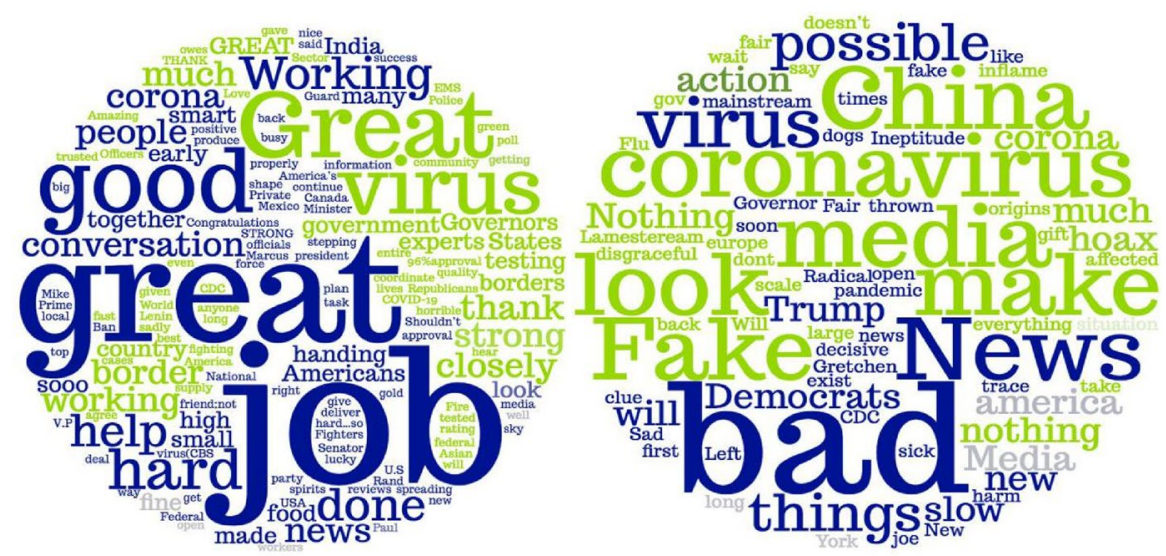

Fig. 1 Vocabulary describing the us-group and the others-group

battle against coronavirus, but the Democrats could only do things that made their Party look sad. In addition, Donald Trump compared the results of the swine flu outbreak with COVID-19, pointing out that former President Obama "took 6 months to declare a national emergency, (and) killed 12,000 Americans" (T042), while he took quick and early action to control the COVID-19 outbreak with a strong border policy which caused fewer deaths. He wanted to convince readers that he did a better job than former President Obama in handling the outbreak of a pandemic. In reality, the results showed that the death toll from the outbreak of COVID-19 was rising unexpectedly.

Repetition is another method by which Donald Trump used his tweets to emphasize the positive us-group and the negative others-group. By the repetition of some positive words, first-person pronouns, and nicknames, Donald Trump described a positive image of the us-group and a negative image of the others-group. In particular, he used positive words like great (38 times) and good (16 times), first-person pronouns (136 times), "we" (51 times), "I" (32 times), and "our" (37 times) for the us-group, while he used third-person pronouns (95 times), "it" (34 times), "they" (30 times), "their" (17 times) and he (14 times), and nicknames like "The Do Nothing Democrats" (7 times), "Chinese virus" (8 times), and "crazy Nancy" (twice) for the others-group. The use of a repetition strategy agrees with the findings of Bustan and Alakrash (2020), Kreis (2017), and Kerbleski (2019). Anggraini et al. (2021) found that Trump used specific nouns modified by adjectives to form a political barrier of antagonism between the us-group and the others-group. Repetitions of nicknames like "The Do Nothing Democrats" were utilized to deride the appearance or belief of opponents (Johnson, 2021).

In the 128 tweets, Donald Trump also used capitalization to emphasize the appropriate and quick actions he took to describe the good job achieved by the us-group with the use of GREAT ( 5 times) and VERY (5 times). These findings are similar to previous studies (Kerbleski, 2019; Van Dijk, 2006). When looking at collocation and context, "GREAT" is always collocated with "job", which is used to praise what 
the us-group has done, and "VERY" is always collocated with "early" to strengthen and confirm that he took very early and appropriate actions to contain COVID-19.

Furthermore, Donald Trump adopted metaphors to reveal his ideologies as well which share the same strategy as described in a previous study (Elaf \& Hussien, 2020). A metaphor is a figure of speech in which a word or phrase is applied to an object or action to which it is not normally applicable (Bustan \& Alakrash, 2020). In his tweets, Donald Trump used "enemy" and "bad gift" to refer to COVID-19. By referring to COVID-19 as a "bad gift from China" (T127), he seems to be trying to arouse the hatred of his audience for the others-group, namely China.

Thus Donald Trump's strategies of argumentation, comparison, repetition, capitalization, and metaphors were used to portray a positive us-group and a negative others-group concerning COVID-19. These strategies were used to emphasize the positive actions of the us-group and the negative actions of the others-group. This confirms the ideological square of van Dijk (1997): (1) to emphasize 'our' good properties/actions, (2) to emphasize 'their' bad properties/actions, (3) to minimize 'our' bad properties/actions, and (4) to minimize 'their' good properties/actions'. Hence, meanings are structurally manipulated by the principle of in-group preference and out-group rejection (Chiluwa \& Ajiboye, 2015).

The strategy of portraying a positive us-group is also similar to the four principal strategies of Bhatia (2006): (1) to achieve common ground, or mutual understanding between two ideological opposites. For example, the tweets "us" (51 times) and "together" (13 times) give a positive and united image of "us" versus "others" and (2) to express praise and politically motivated appreciation. For example, "great job" (14 times) is frequently used to praise what the us-group has done; (3) to propose a promising future relationship, for example, "We will be stronger than ever before!" (T053) and "Good things will happen!" (T055), which illustrate how Donald Trump wanted to propose a promising future for the us-group.

\section{Conclusion and Implications}

The current study adopted CDA to explore the hidden meanings behind tweets compiled for the present corpus. This study indicates how Donald Trump described a positive us-group and a negative others-group by typically adopting strategies of argumentation, comparison, repetition, capitalization, and metaphors. Interestingly, there are some changes when descriptions are given to the same actors in the $u s$ group or the others-group. For example, he used positive expressions to describe and praise China for the hard work and great job it had done in handling the outbreak of COVID-19 at the beginning, but later he used many negative expressions for China and finally blamed China for its incompetence and mass deaths.

Apart from distancing "us" from "others", Donald Trump also portrayed a united image of "us" and "others" in his tweets. By repeatedly adopting the pronoun "we' with "together", he intended to distinguish the boundary between "us" and "others". Moreover, when it comes to Democrats, Donald Trump gave them the nickname of "The Do Nothing Democrats" most of the time. However, he, as a Republican, tried to call for Democrats (without using any nicknames) to work 
together with Republicans to protect all Americans. Based on Van Dijk (1997), the different interests between the parties are the main reason for the changes in the relationship and words used in Donald Trump's tweets.

The main findings of this study should contribute to critical thinking of political discourse. Ideologies in general are neither wrong nor right, but rather more or less effective in promoting the interests of a group. It is assumed that the main social function of ideologies is the coordination of the social practices of group members for the effective realization of the goals of a social group and the protection of its interests. This applies both to internal group social practices as well as to interaction with members of other groups. Therefore, when reading political discourse, we need to identify all the actors involved and group the related descriptions to find out the hidden ideologies. In addition, the positive and negative representations of the actors should be taken into consideration as they give a clear picture of "us" and "others". The strategies of $u s$-representation and othersrepresentation can provide a clue as to what is being implied.

Finally, there are several implications for further studies. First, the present study only selected the posts written by Donald Trump and the retweets in his account were excluded. Further studies can collect all his retweets related to COVID-19 to investigate their resources and functions and then identify what is regarded as the authentic information in his tweets and what ideologies are implied. Second, to obtain a deeper discourse analysis of the ideologies involved, it would be better to interview some Twitter users about their perceptions of Donald Trump's tweets to investigate their ideological influence on users. Finally, it may be interesting to analyze the comments of the retweets forwarded by Donald Trump, since the discourse in the comments may also show some interaction with the ideology of the original tweets. Hence, it would be useful to investigate the impact of Trump's tweets on the perceptions of Twitter users by analyzing their comments.

Authors' Contributions XL: Conceptualization, Methodology, Investigation, and Writing Original Draft. MH: Data collection and review of the paper. ZY: Supervision and Funding acquisition.

Funding 2019 MOOC of Beijing Language and Culture University (MOOC201902) (Important) "Introduction to Linguistics"; "Introduction to Linguistics" of online and offline mixed courses in Beijing Language and Culture University in 2020; Special fund of Beijing Co-construction Project-Research and reform of the "Undergraduate Teaching Reform and Innovation Project" of Beijing higher education in 2020-innovative "multilingual +" excellent talent training system (202010032003).

Availability of Data and Material We make sure that all data and materials support our published claims and comply with field standards.

\section{Declarations}

Conflict of interest The authors declare that they have no conflict of interest. 


\section{References}

Anggraini, R., Sawirman, S., \& Marnita, R. (2021). The Structures of Trump's Political Discourse. IJOTL-TL: Indonesian Journal of Language Teaching and Linguistics, 6(1), 55-72.

Baker, P. (2006). Using corpora in discourse analysis. Continuum.

Bhatia, A. (2006). Critical discourse analysis of political press conferences. Discourse and Society, 17(2), 173-203. https://doi.org/10.1177/0957926506058057.

Budhwani, H., \& Sun, R. (2020). Creating COVID-19 Stigma by Referencing the Novel Coronavirus as the "Chinese virus" on Twitter: Quantitative Analysis of Social Media Data. Journal of Medical Internet Research, 22(5), e19301. https://doi.org/10.2196/preprints.19301

Bustan, E., \& Alakrash, H. (2020). Critical discourse analysis of Donald Trump's tweets addressing the middle eastern countries. International Journal of Future Generation Communication and Networking, 13(2), 407-414.

Chiluwa, I., \& Ajiboye, E. (2015). We are after ideals': A critical analysis of ideology in the tweets by Boko Haram. Global Media Journal African Edition, 8(2), 318-346.

Clarke, I., \& Grieve, J. (2019). Stylistic variation on the Donald Trump twitter account: A linguistic analysis of tweets posted between 2009 and 2018. PLOS ONE, 14(9), 1-27. https://doi.org/10.1371/ journal.pone. 0222062

Darweesh, A. D., \& Abdullah, N. M. (2016). A Critical Discourse Analysis of Donald Trump's Sexist Ideology. Journal of Education and Practice, 7(30), 87-95.

Davari, S., \& Moini, M. R. (2016). The representation of social actors in top notch textbook series: A critical discourse analysis perspective. International Journal of Foreign Language Teaching and Research, 4(13), 69-82.

Elaf, B., \& Hussien, A. (2020). Critical Discourse Analysis of Donald Trump's Tweets Addressing the Middle Eastern Countries. International Journal of Future Generation Communication and Networking, 13(2), 26-38.

Farrelly, M. (2019). Analysing the representation of social actors: The conceptualisation of objects of governance. In N. M. Montessori, M. Farrelly \& J. Mulderrig (Eds.), Critical Policy Discourse Analysis (pp. 147-168). Edward Elgar Publishing. https://doi.org/10.4337/9781788974967.00012

Haman, M. (2020). The use of Twitter by state leaders and its impact on the public during the COVID19 pandemic. Heliyon, 6(11), e05540.

Johnson, T. (2021). Sleepy Joe? Recalling and Considering Donald Trump's Strategic Use of Nicknames. Journal of Political Marketing. https://doi.org/10.1080/15377857.2021.1939572

Kang, H. S., \& Dykema, J. (2017). Critical discourse analysis of student responses to teacher feedback on student writing. Journal of Response to Writing, 3(2), 6-35.

Kerbleski, E. (2019). Trump, Twitter, and the Trees: A Critical Discourse Analysis of. Donald Trump's Tweets Surrounding the November 2018 California Wildfires (Doctoral dissertation, Northern Arizona University).

Khan, M. H., Adnan, H. M., Kaur, S., Khuhro, R. A., Asghar, R., \& Jabeen, S. (2019). Muslims' representation in Donald Trump's anti-Muslim-Islam statement: A critical discourse analysis. Religions, 10(2), 115. https://doi.org/10.3390/rel10020115

Klaus, J., \& Koser, C. (2021). Measuring Trump: The Volfefe index and its impact on European financial markets. Finance Research Letters, 38, 101447. https://doi.org/10.1016/j.frl.2020.101447

Kreis, R. (2017). The "tweet politics" of former President Trump. Journal of Language and. Politics, 16(4), 607-618. https://doi.org/10.1075/j1p.17032.kre

Leung, R. C. (2016). A Critical discourse Study of a German Children's Book Series: Representation of Social Actors and Construction of Legitimation. International Journal of Linguistics, 8(5), 89-106. https://doi.org/10.5296/ijl.v8i5.10057

Lockhart, M. (2019). President Donald Trump and his political discourse: Ramifications of rhetoric via Twitter. Routledge.

Martin, J. (2013). Politics and rhetoric: A critical introduction. Routledge.

Mena García, T. (2018). Donald J. Trump: A Critical Discourse Analysis I Donald J. Trump: un análisis crítico del discurso. Revista Estudios Institucionales, 5(8), 47. https://doi.org/10.5944/eeii. vol.5.n.8.2018.21778

Meyer, M., \& Wodak, R. (2009). Critical discourse analysis: history, agenda, theory and methodology. In R. Wodak \& M. Meyer (Eds.), Methods for critical discourse analysis (pp. 1-34). Sage Publishing. 
Mullet, D. R. (2018). A General Critical Discourse Analysis Framework for Educational Research. Journal of Advanced Academics, 29(2), 116-142. https://doi.org/10.1177/1932202X18758260

Ott, B. L. (2017). The age of Twitter: Donald J. Trump and the politics of debasement. Critical Studies in Media Communication, 34(1), 59-68. https://doi.org/10.1080/15295036.2016.1266686

Piksar, K. (2018). Donald Trump's political discourse on Twitter (Doctoral dissertation, Tartu Ülikool).

Rahimpour, S., Sotoudehnama, E., \& Sasani, F. (2018). Investigating Researcher Identity in Qualitative Research Articles in Applied Linguistics Journals through the Lens of CDA. Journal of Research in Applied Linguistics, 9(2), 74-100. https://doi.org/10.22055/RALS.2018.13794

Rohmah, S. N. (2018). Critical discourse analysis of Donald J. Trump's speeches (Doctoral dissertation, UIN Sunan Ampel Surabaya).

Ross, A. S., \& Caldwell, D. (2020). 'Going negative': An appraisal analysis of the rhetoric of Donald Trump on Twitter. Language and Communication, 70, 13-27. https://doi.org/10.1016/j.langcom. 2019.09.003

Samadikhah, M., \& Shahrokhi, M. (2015). A Critical Discourse Analysis of ELT Materials in Gender Representation: A Comparison of "Summit" and "Top Notch." English Language Teaching, 8(1), 121-133. https://doi.org/10.5539/elt.v8n1p121

Sarani, A., \& Kord, S. (2018). A Study of the Representation of Social Actors in TouchstoneSeries: A Critical Discourse Analysis Perspective. Teaching English Language, 12(1), 111-133. https://doi. org/10.22132/tel.2018.60132

Schertzer, R., \& Woods, E. (2021). \# Nationalism: The ethno-nationalist populism of Donald Trump's Twitter communication. Ethnic and Racial Studies, 44(7), 1154-1173. https://doi.org/10.1080/ 01419870.2020 .1713390

Shafer, J. G. (2017). Donald trump's "political incorrectness": Neoliberalism as frontstage racism on social media. Social Media and Society, 3(3). https://doi.org/10.1177/2056305117733226

Taiwo, B. R. (2007). Language, ideology and power relations in Nigerian Newspaper headlines. Nebula, $4(1), 218-245$.

Tasente, T. (2020). Twitter Discourse Analysis of US President Donald Trump. Technium Social Sciences Journal, 2, 67-75. https://doi.org/10.47577/tssj.v2i1.49

Teguia, M. C. (2019). Donald Trump's tweets on the border wall: A critical discourse analysis (Doctoral dissertation, University of Mostaganem).

Van Dijk, T. A. (1997). Opinions and ideologies in the press. In P. Garrett \& A. Bell (Eds.), Approaches to Media Discourse (pp. 21-62). Blackwell Publishing.

Van Dijk, T. A. (2006). Discourse and Manipulation. Discourse and Society, 17(3), 359-383. https://doi. org/10.1177/0957926506060250

Van Holm, E. J., Monaghan, J., Shahar, D. C., Messina, J., \& Surprenant, C. (2020). The impact of political ideology on concern and behavior during COVID-19. SSRN Electronic Journal, 1-27. https:// doi.org/10.2139/ssrn.3573224

Wodak, R. (2001). What CDA is about: A summary of its history, important concepts and its developments. In R. Wodak \& M. Meyer (Eds.), Methods of critical discourse analysis (pp. 1-12). Sage Publishing. https://doi.org/10.4135/9780857028020.n1

Yaqub, U., Chun, S. A., Atluri, V., \& Vaidya, J. (2017). Analysis of political discourse on Twitter in the context of the 2016 US presidential elections. Government Information Quarterly, 34(4), 613-626. https://doi.org/10.1016/j.giq.2017.11.001

Yum, S. (2020). Social Network Analysis for Coronavirus (COVID-19) in the United States. Social Science Quarterly, 101(4), 1642-1647. https://doi.org/10.1111/ssqu.12808

Zahra, M. S. (2019). Racism in Donald Trump's Tweets: A Critical Discourse Analysis (Doctoral dissertation, University of Mostaganem).

Publisher's Note Springer Nature remains neutral with regard to jurisdictional claims in published maps and institutional affiliations. 


\section{Authors and Affiliations}

\section{Xue Luo ${ }^{1,2}\left(\mathbb{C} \cdot\right.$ Mei He$^{3}(-) \cdot$ Zhonggen $\mathrm{Yu}^{4}(\mathbb{0}$}

Xue Luo

candicelx@foxmail.com

Mei He

hmei0639@gmail.com

1 School of Foreign Languages, Suranaree University of Technology, 111 University Avenue, Suranaree Sub-District, Muang Nakhon Ratchasima District, Nakhon Ratchasima 30000, Thailand

2 College of International Studies and Education, Tongren University, Tongren, China

3 School of Foreign Languages, Institute of Social Technology, Suranaree University of Technology, 111 University Avenue, Suranaree Sub-District, Muang Nakhon Ratchasima District, Nakhon Ratchasima 30000, Thailand

4 Faculty of Foreign Studies, Beijing Language and Culture University, Beijing, China 